\title{
Sobre o dossiê FHC
}

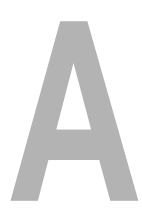

o organizar este número especial Tempo Social, busca-se cumprir, com os meios de se que dispõe, o que se considera uma das responsabilidades da Universidade: analisar criticamente o modo como vem sendo conduzidos os negócios públicos no país.

Não se trata obviamente de responsabilidade inscrita em lei ou estatuto. Nem de encargo derivável da natureza da Universidade. Trata-se de uma responsabilidade reivindicada, por quem entende que a Universidade, como centro de transmissão e produção de saber mantido pelo poder público, deve pôr-se em sintonia com o movimento democratizante que atravessa a sociedade.

Embora a missão de analisar crítica mas objetivamente as atividades governamentais sempre seja espinhosa, o fato de estar em questão o primeiro governo de Fernando Henrique Cardoso multiplica as dificuldades.

A própria origem acadêmica do presidente da República e de um número expressivo de seus auxiliares torna mais intrincada a usualmente complexa relação entre sujeito e objeto de conhecimento. Quando se analisa o governo Fernando Henrique, a dificuldade não provém apenas de os cientistas sociais serem parte da própria sociedade da qual destacam um aspecto para analisarem. O nó está também no fato de que o objeto de investigação tem no seu núcleo o que era, até há pouco, parte significativa do "mundo acadêmico" - intelectuais que constituíam marcos importantes do seu sistema de referências e com quem, por vezes, os sujeitos da investigação mantém ou, pelo menos, mantinham relações profissionais e afetivas.

Isso já não seria pouco, mas não é tudo. A dificuldade não aumenta apenas porque participantes significativos da "comunidade acadêmica" se transferiram para o governo em exame, mas também porque o contato dessa comunidade com a política nacional não tem sido epidérmico. Nas últimas décadas, vem ocorrendo o contrário. Nos anos 70, uma parte da comunidade acadêmica passou a participar ativamente da vida política nacional, fazendo oposição ao regime militar por meio de várias vias institucionais - SBPC, imprensa nanica, MDB, etc. Depois, na década de 80, quando a oposição política segmentou-se em distintos partidos, a comunidade seguiu-lhe os passos, desdobrando-se em tendências políticas distintas e participando tanto do debate público, das campanhas eleitorais e dos movimentos de massa como também do exercício do 
poder de Estado, seja no plano federal, estadual ou municipal. O mundo acadêmico tem se mostrado, pois, permeável à política nacional, tem sido transpassado, dividido e envolvido por divisões e conflitos políticos.

Ademais, com a passagem dos anos 80 para a década de 90 , as fraturas político-ideológicas existentes no meio acadêmico ganharam outra dimensão. Na nova década, tanto o núcleo da agenda política deslocou-se da democratização para a liberalização econômica, acompanhando as mudanças em curso em âmbito mundial, como as forças políticas redefiniram suas posições no plano nacional. Esta redefinição de agenda e de posicionamento político ocorreu aos poucos, atingindo o auge no governo Fernando Henrique. Oimpacto dessas mudanças sobre a ideologicamente já dividida "comunidade" acadêmica foi enorme. Divergências em torno de meiose diferenças de ênfase em relação a objetivos políticos similares não deixaram de existir, mas foram deslocadas por contraposições mais profundas ancoradas em valores contrapostos. Em meio a essas divisões, as ações de governo tendem a ser qualificadas de forma absoluta, negativa ou positivamente, conforme sua identificação com os valores em confronto.

Certamente, algumas dessas circunstâncias prejudiciais à análise sociológica do governo Cardoso seriam minimizadas com o tempo. De fato, a circunstância de se fazer uma análise "sem perspectiva histórica", isto é, com os analistas envolvidos pelo mesmo confronto de valores em disputa na arena política, dramatiza as dificuldades inerentes à produção de conhecimentos nas ciências sociais. Mas é justamente essa contemporaneidade que torna mais relevante a tarefa do ângulo da construção da democracia.

Os cientistas sociais convidados por Tempo Social responderam ao desafio que lhes foi proposto com análises que constituem, em conjunto, avanço significativo na compreensão da história contemporânea. É notável o esforço que se fez para reconstituir de forma cuidadosa e equânime cada política examinada e o governo como um todo.

Os aspectos abrangidos pelos artigos aqui publicados certamente não esgotam todas as áreas da atuação governamental e nem mesmo todas as cuidadas por ministérios específicos. As limitações de espaço tornaram isso inevitável. Mesmo assim, cobriu-se uma ampla faixa das atividades de governo - a política econômica e as relações Estado/mercado, a reordenação da Federação, as relações Executivo/Legislativo, as políticas sociais, de educação, de saúde, de segurança pública, as relações Estado/trabalhadores urbanos e Estado/propriedade agrária/trabalhadores rurais.

Não cabe aqui expor o conteúdo de cada um dos artigos, mas apenas manifestar a esperança de que a sua leitura constitua estímulo para que se intensifique o debate qualificado sobre o modo como se vem governando a sociedade brasileira. Se assim for, este número terá colocado o seu tijolo no processo de construção da democracia. 